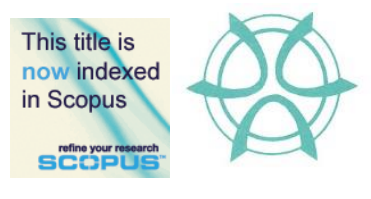

PLANNING MALAYSIA:

Journal of the Malaysian Institute of Planners

VOLUME 16 ISSUE 2 (2018), Page 30 - 38

\title{
METAL EXPOSURE IN RESPIRABLE \& INHALABLE DUST BY THE LOCALITY OF COAL-FIRED POWER PLANT
}

\author{
Shamzani Affendy Mohd Din ${ }^{1}$, Nik Nurul-Hidayah Nik Yahya ${ }^{2} \&$ Rashidi \\ Othman $^{3}$ \\ ${ }^{1,3}$ Kulliyyah of Architecture and Environmental Design \\ INTERNATIONAL ISLAMIC UNIVERSITY MALAYSIA \\ ${ }^{2}$ Faculty of Engineering and Green Technology \\ UNIVERSITI TUNKU ABDUL RAHMAN, MALAYSIA
}

\begin{abstract}
The surrounding area of the coal-fired power plant are mostly exposed to its chemical contents. The world has witnessed multicases relevant to mortality due to overexposure to coal materials. However, these factor have not been faced by the Malaysians. Still, it is significant to monitor and control the coal-fired power plant exposure. This research aims to identify the dominant metal within the radius of a coal-fired power plant combustion source point. The inhalable and respirable dust are being collected then analysed and calculated its Permissible Exposure Limit (PEL). Later, health impact knowledge is being synchronize with the obtained data. Hence, built environment at the radius $5 \mathrm{~km}, 10 \mathrm{~km}, 15 \mathrm{~km}$ and $20 \mathrm{~km}$ were being observed as well as inhalable and respirable dust. The data was analysed using the ICPMS (Nexion 300x) to trace the concentrations of metals. The metals include $\mathrm{Ba}, \mathrm{Cr}, \mathrm{Cu}, \mathrm{Fe}, \mathrm{Mn}, \mathrm{Ni}, \mathrm{Pb}, \mathrm{V}$, and $\mathrm{Zn}$. Generally, the results showed that the total of respirable towards inhalable dust ratio of metal concentration found at Manjung was $88.62 \%$. The highest concentration found in Iron was at $4.710 \mathrm{ng} \mathrm{m-3}$ for respirable dust and Zinc for inhalable dust at 7.387 ng m-3; thus, claiming both Iron and Zinc as the dominant metals in Manjung. The pattern of metals concentration found in this research proven that the FGD and ESPs application in Manjung coal-fired power plant contributed in reducing the airborne particles emissions. However, the PEL calculations showed exceeding limits of metals found on site. Hence affecting the human respiratory, cardiovascular and nervous systems. Therefore, new research in developing the policy for the construction of the coal-fired power plant, especially within the radius of residential and public area are in significant need.
\end{abstract}

Keywords: coal-fired power plant, residential, metal, inhalable dust, respirable dust 
PLANNING MALAYSIA

Journal of the Malaysia Institute of Planners (2018)

\section{INTRODUCTION}

Airborne particles overexposure is believed to bring certain human disease (Wilson, 2015). Meetham, Bottom, Cayton, Henderson-Sellers and Chambers (1981) stress that the coal burning in the cities contributing to air pollution to human health was the direct effect of the airborne particles since 40 years ago. In a tragedy of London smog in the year 1952, there were about four thousand $(4,000)$ premature deaths occurred.

In Manjung population scenario, the residents with nearest to $500 \mathrm{~m}$ radius experienced many years of living in areas with high particle levels emitted from the coal-fired power plant. They were exposed to the risk of facing development of chronic bronchitis, premature death, decreased lung function and cardiovascular mortality (EPA, 2004; Lockwood, Welker-Hood, Rauch, Gottlieb, 2009). However, as for the visitors' condition, they were exposed to short-term coal particulate matter pollution either for hours or days. They would face risks of heartbeat irregularities, heart attacks, hospital admissions faulty respiratory symptoms, decreased lung function, increased emergency room visits for heart or lung diseases and premature deaths. These impacts on health would have a greater risk towards elderlies, children and people with heart or lung disease.

According to the US EPA (2004), the airborne particles cause adverse impacts on health towards human being. The sizes play a vital role, as the largest airborne particles provide lesser impact on health. While the coarse and fine particles lead to a health problem since they can be deposited into the lung and bloodstream. It is to be highlighted that the coal airborne particle is at the average size of less than $2.5 \mu \mathrm{m}$ called $\mathrm{PM}_{2.5}$. Therefore, it is also believed that it can be deposited into the lung system and causes respiratory illness (Wilson, 2015).

Moreover, Lockwood et al. (2009), emphasised that the coal airborne particles also affect all major organ systems of the body. Those are respiratory, cardiovascular and nervous systems. Contaminants from coal combustion processes can lead to a decrease in lung development of children, asthma, lung diseases and lung cancer. Furthermore, coal particulates could also affect the cardiovascular system by causing artery blockage that lead to heart attacks, cardiac arrhythmias, congestive heart failure and tissues death due to oxygen deprivation that root towards permanent heart damage. Furthermore, failure of nervous system could also transpire due to exposure from coal particulate matter. It is believed that coal contaminant could lead to stroke.

The aim of this research is to identify the dominant metal in both inhalable and respirable dust collected at the radius of a coal-fired power plant by measuring its Permissible Exposure Limit (PEL). Then, health impact knowledge was compared with the obtained data.

\section{RESEARCH METHODOLOGY}

Analysis of metals at 10 different sampling sites, each with different site 
Shamzani Affendy Mohd Din, Nik Nurul-Hidayah Nik Yahya \& Rashidi Othman

Metal Exposure in Respirable \& Inhalable Dust by The Locality of Coal-Fired Power Plant

background, by using the personal sampling pumps of airborne particles with cyclone and seven-hole heads was conducted. 20 contaminated samples were collected from 10 sampling points. The location of the sampling points are indicated in Figure 1.

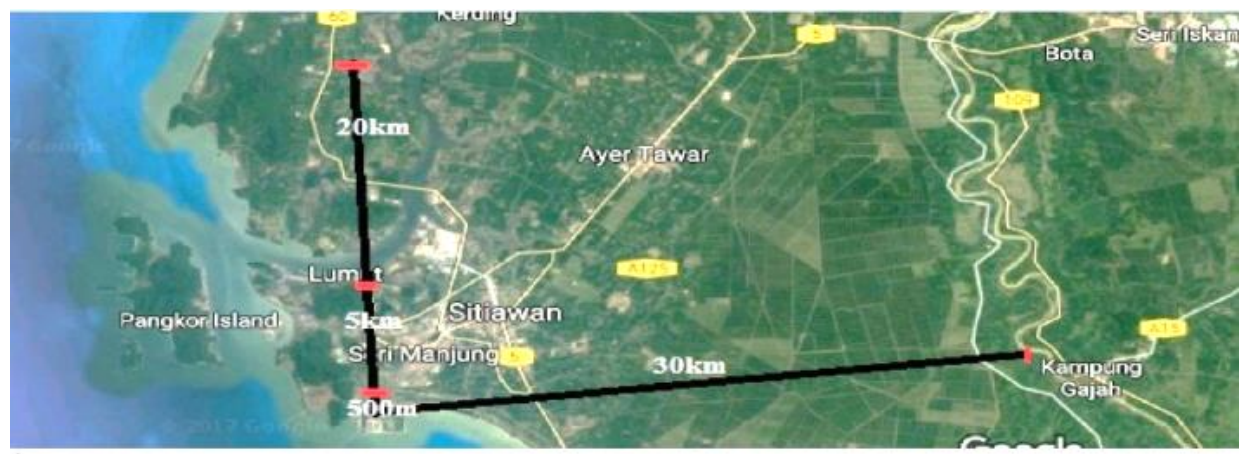

Figure 1: Map of Manjung with radius distance to Manjung Coal-fired Power Plant

It was done between two classifications of sizes of airborne particles which were respirable and inhalable dust. The metal contents test by using the ICPMS was done to determine the amount of concentrations of $\mathrm{Ba}, \mathrm{Cr}, \mathrm{Cu}, \mathrm{Fe}, \mathrm{Mn}, \mathrm{Ni}$, $\mathrm{Pb}, \mathrm{V}$ and $\mathrm{Zn}$, measured in SI unit of $\mathrm{mg} / \mathrm{m}^{3}$. The comparison of metal contents found from the power plants were analysed through this analysis by means of analysis of variance and bar chart illustrations.

\section{RESULTS AND DISCUSSION}

The results in Figure 2 shows that the range of the readings in Manjung and Segari was about the same although the distance was $20 \mathrm{~km}$ away. However, contradictions was observed in the results at the car park area of Lumut Gas Cycle Power Plant. Another pattern of reading could be seen from the results at both building in Lumut which were the shop lots and residential area.

Moreover, the ratio of respirable dust to inhalable dust at shop lot units in Lumut read $124.45 \%$ which was higher than both sites in Segari that accumulated $109.58 \%$ and $91.45 \%$, at Segari police station and shop lots, respectively. This amount was higher than the ratio found in Manjung. It could be viewed that the ratio of respirable dust to inhalable dust nearby Manjung Power Plant and Lumut residential area occupied lower ratio at $88.52 \%$ and $73.19 \%$. It is observed that the pattern was not consistent with the area, but to the distance to the road traffic. 
PLANNING MALAYSIA

Journal of the Malaysia Institute of Planners (2018)

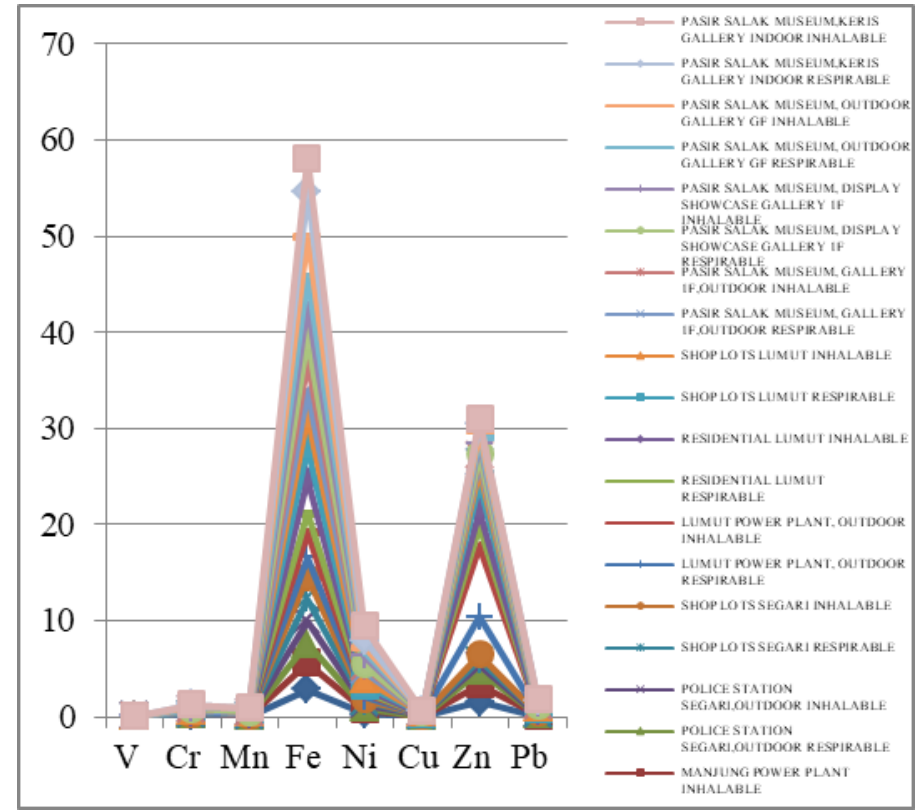

Figure 2: Concentrations of metal in respirable and inhalable dust sample collected at the locality of Manjung coal-fired power plant

Furthermore, at Pasir Salak Historical Complex, the ratio at the outdoor gallery in level one was higher than the ground floor at $25.36 \%$. Additionally, the display showcase at gallery had lower respirable to inhalable dust ratio at $67.28 \%$. From the entire samples collected in Pasir Salak Historical Complex, the indoor of ground floor result showed the highest concentration of respirable to inhalable dust ratio at $114.60 \%$. Thus, it had a high risk towards the health of the personnel and visitors of this heritage sites.

The results further support the findings by Janssen, Hoek, Brunekreef, and Harssema (1999), and Oeder et al. (2012), where human presence offers multiple human activities which contributed to the ambient. The presence of indoor Pasir Salak Historical Complex respirable and inhalable dust was also contributed by the resuspension of soil dust from the outside that was brought in by the visitors and personnel's shoes on the carpets. Similarly, Janssen et al. (1999) found that the soil element had the highest I/O ratio while the combustion source had the lowest I/O ratio. The findings also clarified the reason of higher indoor air metal concentrations than in the outdoor air.

Furthermore, human activities at each locality affected the metal concentrations found in the collected respirable and inhalable dust. The activities of the residents in Manjung supported this result by showing high Iron and Zinc metal concentration. The result for Zinc element was similar with the result in the chapter above at $5 \mathrm{~km}$ away from the coal-fired power plant. Thus, strongly 
Shamzani Affendy Mohd Din, Nik Nurul-Hidayah Nik Yahya \& Rashidi Othman

Metal Exposure in Respirable \& Inhalable Dust by The Locality of Coal-Fired Power Plant

suggesting that the combustion was from coal sources. The high respirable to inhalable dust ratio exceeded half of the full percentage was in line with the previous studies (Yi et al., 2008; Saarnio et al., 2014; Wilson, 2015) on the high amount of fine and ultrafine airborne particles found due to the coal combustion exposure. In agreement with a few researchers (Zhang et al., 2015; Kulshrestha, Massey, Masih, \& Taneja, 2014; Cassee, Héroux, Gerlofs-Nijland, \& Kelly, 2013) high Zn element in respirable dust was believed to cause stronger impacts on health to the Manjung population.

The results were supported by the previous researchers (Tahir, Suratman, Foo, Hamzah, \& Latif, 2013; Wahid et al., 2014; Abbasi, Tufail, \& Chaudhry, 2013; Kulshrestha et al., 2014; Che, Frey, \& Lau, 2015; Zhang et al., 2015). Fe was still traced higher than $\mathrm{Zn}$ at most sampling areas in Manjung indicating that the humic gley soil entrainment and traffic emissions contributed to this result. Other sources include the traces of $\mathrm{Fe}$ and $\mathrm{Zn}$ elements at Manjung from the nearby metal steel factory (Zhang et al., 2015; Pekney et al., 2006) cement batching plant, and cooking combustion. Palomo, Alonso, Fernandez-Jiménez, Sobrado and Sanz (2004) stressed that fly ash is suitable to become the alkaliactivated for cement due to the vitrous phase contents, particle size distributions and reactive silica content of fly ash. Therefore, the cement batching plant supported this finding. Non-combustion, lubricating and grease oil sources also caused the existence of $\mathrm{Zn}$ metal element on site. This was supported by few researches (Tahir et al., 2013; Wahid et al., 2014; Abbasi et al., 2013; Zhang et al., 2015). Moreover, it was found that both of the results in Segari and Manjung supported the idea of Kulshrestha et al. (2014) where the agriculture and construction sites observed, the results showed high $\mathrm{Zn}$ due to the heavy vehicular activities. $\mathrm{Zn}$ elements were found the highest in both respirable and inhalable dust due to the gas cycle turbine process. The secondary components which came from the reactions of the power plant equipment, which were the causes of the releases of inhalable dust, were found higher than the combustion sources.

Consistent results were obtained at every sampling location in Manjung. Only the Lumut Gas Cycle Power Plant had a contradicting result with Zinc element was found the highest in respirable dust. Therefore, it was strongly suggested that the combustion from coal sources were very reachable to this area. The pattern in Pasir Salak Historical Complex also showed high Ni metal element too, apart of Iron and Zinc. Comparing the results with the chemical elements of coal used for the coal-fired power plant in Manjung, it was strongly agreed that the Ni element could possibly come from the coal combustion. This high amount of Nickel element also proved the presence of human (visitors and personnel) at this area due to dust brought in by the skin, clothes, shoes, or the handling of materials (movement of handbags, brochures paper etc.). The soil dust deposited in carpets and acted as a sink. The walking and sitting causing the dust to crush against each other, thus compressing the carpets and creating a high velocity air 
PLANNING MALAYSIA

Journal of the Malaysia Institute of Planners (2018)

flow. This generates the airborne particles from the carpet. This is in agreement with the finding by Branis, Rezacova and Domasova (2005).

Findings at Pasir Salak Historical Complex were in contradiction with Branis et al. (2005), as the results showed that the inhalable dust metal concentrations were lower than the respirable dust found. Therefore, it was found that Pasir Salak Historical Complex indoor airborne particles were contributed most by the combustion sources from the outdoor areas that infiltrated through the glass door and the gaps between the wood floor panels. The usage of the HVAC was another triggering factor that caused high wind velocity to the indoor gallery ambient. Thus, this forced local turbulence to take place indoor by HVAC. This high velocity air flow let the combustion airborne particles from outdoor to be transported, resuspended and deposited indoor. This is supported by Baron and Willeke (2011) that the particle removals from surfaces are by air flow.

The coal combustion could cause adverse impacts on human health. This includes the residents or personnel who have inhaled the airborne particles for a long period of time or the visitors who inhaled the airborne particles for a short period of time. The standard for indoor concentration was referred to Permissible Exposure Limit, which was calculated based on the eight-hour TWA DOSH limitations, shows that none of the metal elemental concentrations exceed the limit. Similarly, the outdoor concentrations also did not exceed the limit specified by the Malaysia Environmental Quality Act regulation. However, following Table 1 are the diseases from iron as its presence was dominant in the metal concentrations in Manjung area. 
Shamzani Affendy Mohd Din, Nik Nurul-Hidayah Nik Yahya \& Rashidi Othman

Metal Exposure in Respirable \& Inhalable Dust by The Locality of Coal-Fired Power Plant

Table 1 Health diseases due to excessive exposure of $\mathrm{Fe}$ and $\mathrm{Pb}$. Iron related health diseases

- Large amounts of free iron in the circulation causes damage to critical cells in the liver, the heart and other metabolically active organs.

- Endocrinological

- Gastrointestinal

- Infextious

- Neoplasmic

- Endocrinological

- Gastrointestinal

- Infections

- Orthopedic

- Pulmonary and vascular disease

- Alzheimers

- Parkinson

- Artherosclerosis

- Mortality

- Pathogenic invasions Source: US EPA (2015), Flora (2014), Ghosh (2014), Wilson (2015)

\section{CONCLUSION AND RECOMMENDATIONS}

The results in general showed that the total respirable dust to inhalable dust ratio of metal concentration found at Manjung was $88.62 \%$. The highest concentration found in Iron was at $4.71 \mathrm{ng} \mathrm{m}^{-3}$ for respirable dust and Zinc for inhalable dust at $7.387 \mathrm{ng} \mathrm{m}^{-3}$; thus, claiming both Iron and Zinc as the dominant metals in Manjung. The trace elements were also not aligned with traced metal in the coal test made in Kalimantan. Hence verifies that the FGD and ESPs application in Manjung coal-fired power plant had achieved its target in reducing the airborne particles emissions. However, it still can affect the human respiratory, cardiovascular and nervous systems.

The government should develop a new policy for the construction of coal-fired power plant, especially within the radius of residential and public area. It is also advisable for air pollutant experts and researchers in Malaysia to continuously monitor and collect samples from the locality of Manjung coal-fired power plant, especially during hot weather.

\section{ACKNOWLEDGEMENT}

The author would like to acknowledge the FRGS 13-013-0254 grant by Ministry of Higher Education and International Islamic University Malaysia for facility supports to make this research possible. 
PLANNING MALAYSIA

Journal of the Malaysia Institute of Planners (2018)

\section{REFERENCES}

Abbasi, M. N., Tufail, M. A., \& Chaudhry, M. M. (2013). Assessment of heavy elements in suspended dust along the Murree Highway near capital city of Pakistan. World Applied Science Journal, 21(9), 1266-1275.

Baron, P. A. \& Willeke, K. (Eds.) (2011). Aerosol measurement: Principles, techniques and applications. (2nd Edition). New York: Wiley-Inter-Science.

Branis, M., Rezacova, P., \& Domasova, M. (2005). The effect of outdoor air and indoor human activity on mass concentrations of $\mathrm{PM}_{10}, \mathrm{PM}_{2.5}$, and $\mathrm{PM}_{1}$ in a classroom. Environmental Research, 99(2), 143-149.

Cassee, F. R., Héroux, M.-E., Gerlofs-Nijland, M. E., \& Kelly, F. J. (2013). Particulate matter beyond mass: recent health evidence on the role of fractions, chemical constituents and sources of emission. Inhalation Toxicology, 25(14), 802-812.

Che, W. W., Frey, H. C., \& Lau, A. K. H. (2015). Comparison of sources of variability in school age children exposure to ambient $\mathrm{PM}_{2.5}$. Environmental Science\& Technology, 49(3), 1511-1520.

Flora, S. J. (2014). Toxic metals: Health effects, and therapeutic measures. Journal of Biomedical and Therapeutic Sciences, 1(1), 48-64.

Ghosh, M. K. (2014). An analysis of roadside dust fall in Bhilai-3 of Durg District Chhattisgarh, Central India and its impact on human health. International Journal of Research in Environmental Science and Technology, 4(2), 54-60.

Janssen, N. A., Hoek, G., Brunekreef, B., \& Harssema, H. (1999). Mass concentration and elemental composition of $\mathrm{PM}_{10}$ in classrooms. Occupational and Environmental Medicine, 56(7), 482-487.

Kulshrestha, A., Massey, D. Masih, J., \& Taneja, A. (2014). Source characterization of trace elements in indoor environments at urban, rural and roadside sites in a semi-arid region of India. Aerosol and Air Quality Research, 14, 1738-1751

Lockwood, A. H., Welker-Hood, K., Rauch, M., \& Gottlieb, B. (2009, November 12). Coal's assault on human health. Retrieved from https://www.psr.org/blog/resource/coals-assault-on-human-health/.

Meetham, A. R., Bottom, D. W., Cayton, S., Henderson-Sellers, A., \& Chambers, D. (1981). Atmospheric pollution, its history, origins and prevention ( $4^{\text {th }}$ edition). Oxford; New York: Pergamon Press.

Oeder, S., Dietrich, S., Weichenmeier, I., Schober, W., Pusch, G., Jörres, R. A.,...\& Buters, J. T. (2012). Toxicity and elemental composition of particulate matter from outdoor and indoor air of elementary schools in Munich, Germany. Indoor Air, 22(2), 148-58

Palomo, A., Alonso, S., Fernandez-Jiménez, A., Sobrados, I., \& Sanz, J. (2004). Alkaline activation of fly ashes: NMR study of the reaction products. Journal of the American Ceramic Society, 87(6):1141-1145. 
Shamzani Affendy Mohd Din, Nik Nurul-Hidayah Nik Yahya \& Rashidi Othman

Metal Exposure in Respirable \& Inhalable Dust by The Locality of Coal-Fired Power Plant

Pekney, N. J., Davidson, C. I., Robinson, A., Zhou, L., Hopke, P., Eatough, D., \& Rogge, W. F. (2006). Major source categories for PM2. 5 in Pittsburgh using PMF and UNMIX. Aerosol Science and Technology, 40(10), 910-924.

Saarnio, K., Frey, A., Niemi, J. V., Timonen, H., Rönkkö, T., Karjalainen, P.,...\& Keskinen, J. (2014). Chemical composition and size of particles in emissions of a coal-fired power plant with flue gas desulfurization. Journal of Aerosol Science, 73, 14-26.

Tahir, N. M., Suratman, S., Foo, T. F., Hamzah, M. S., \& Latif, M. T. (2013). Temporal distribution and chemical characterization of atmospheric particulate matter in the eastern coast of Peninsular Malaysia. Aerosol and Air Quality Research, 13(2), 584-595.

US EPA (2004). The particle pollution report: current understanding of air quality and emissions through 2003. Research Triangle Park, NC: US Environmental Protection Agency.

US EPA (2015). Lead Compounds. Technology Transfer Network Air Toxics Websites. Retrieved June, 26, 2015 from http://www.epa.gov/ttn/atw/hlthef/lead.html

Wahid, N. B. A., Latif, M. T., Suan, L. S., Domminick, D., Sahani, M., Jaafar, S. A., \& Mohd Tahir, N. (2014). Source identification of PM in semi-urban area of Malaysia using multi-variate techniques. Bulletin of Environmental Contamination and Toxicology, 92(3), 317-322.

Wilson, L. (2015, May). Lead. Retrieved from drwilson.com/articles/LEAD.htm

Yi, H., Hao, J., Duan, L., Tang, X., Ning, P., \& Li, X. (2008). Fine particle and trace element emissions from an anthracite coal-fired power plant equipped with a bag-house in China. Fuel, 87(10), 2050-2057.

Zhang, N., Han, B., He, F., Xu, J., Niu, C., Zhou, J.,...\& Xu H. (2014). Characterization, health risk of heavy metals, and source apportionment of atmospheric $\mathrm{PM}_{2.5}$ to children in summer and winter: an exposure panel study in Tianjin, China. Air Quality Atmospheric Health, 8(4), 347-357. 